\title{
Parental Work Schedules and Hours in 29 European Countries, 2005-2015: A Welfare State Comparison
}

\author{
Wen-Jui Han, New York University, USA ${ }^{+}$ \\ Pablo Gracia, Trinity College Dublin, Ireland \\ Jianghong Li, WZB Berlin Social Science Center, Germany
}

\begin{abstract}
Using three waves of the European Working Conditions Survey (2005-2015), we examined parental work schedules and hours across welfare regimes covering 29 European countries with attention to gender and socioeconomic gaps $(\mathrm{N}=20,648)$. Multivariate logistic regression results revealed that: (1) nonstandard work schedules and overworking were more prevalent in the Liberal, Southern European, and Central-Eastern European regimes than were in the Corporatist and Social Democratic welfare regimes, whereas underworking was the highest in the Liberal and Corporatist regimes; (2) fathers were more likely to work nonstandard schedules and overwork but less likely to underwork than were mothers, with the strongest gender gaps observed for the Liberal regime; (3) highly-educated parents were less likely to work nonstandard schedules and overwork but more likely to underwork, and this was more pronounced in the Southern European and Central-Eastern European welfare regimes; (4) compared to 2005, nonstandard work schedules were more prevalent in 2015, and both overworking and underworking were less prevalent in 2010; these trends varied across welfare regimes.
\end{abstract}

Keywords: EWCS, parental work hours, work schedules, welfare states.

+ Correspondence: Wen-Jui Han, Silver School of Social Work, New York University, 1 Washington Square North, New York, NY 10003. USA. Email: wjh3@nyu.edu. 


\section{INTRODUCTION}

Work constitutes a central part of an individual's life and indeed people tend to define themselves by the type of work they are engaged with. Work not only shapes individuals' living standards and experiences, but also plays a significant role in (downward/upward) mobility on a socioeconomic ladder within the social structure. Globally, labor markets in recent decades have become increasingly volatile and precarious, evident in vital indicators like earnings, job benefits, work shifts and work hours (Kalleberg, 2013). In today's globalized and digitalized labor market, the norm is no longer the $9 \mathrm{am}-5 \mathrm{pm}$ standard daytime work schedule, and a 40 -hour work week is no longer sufficient for many families to obtain and maintain a decent living standard (Kalleberg, 2013; Presser, 2003a). Parents are increasingly forced to work nonstandard schedules that are unsociable and are seeing more volatility in their work status (e.g., too long of the hours or not enough hours involuntarily), which may weaken their ability to ensure that their offspring have chances to move socioeconomically upward or to prevent downward mobility.

These recent labor market transformations have occurred in parallel with new "social risks" and emerging social inequalities (Kalleberg, 2013). Growth in the service sector, coupling with advances in technology, particularly information technology, have enabled the development of a globalized 24/7 economy. These changes have led to increasing polarizations and precarity in the labor market (Kalleberg, 2013). At one extreme, well-educated and high-skilled workers are rewarded with high income and job-associated benefits, albeit many of them must work long hours at high intensity. At the other extreme, many low-wage and low-skilled workers have been forced to work in more than one job because of precarity (e.g., unstable and unpredictable hours and shifts without job security) (Jacobs \& Gerson, 2001). Growing inequality from one generation to the next could be foreseen if some parents were more vulnerable to polarization and precarity than others. Yet, to date, scholars have provided insufficient evidence on the micro and macro patterns in parental work schedules and hours. 
In this paper, we investigated variations in working schedules and hours among parents across institutional contexts in Europe across a 10-year time span, paying particular attention to how these variations intersect with gender and socioeconomic status.

By focusing on parents with children under the age of 15 , our study makes three key contributions to the literature. First, we investigated two important areas of parental work capturing various possibilities of precarious employment: (i) the type of hours (i.e., nonstandard shifts defined as hours that are during early mornings, evenings, nights, weekends, or variable) and (ii) the number of hours with overwork defining as working 45 or more hours per week and with underwork defining as working 25 or fewer hours per week. Previous studies show that nonstandard schedules are closely associated with low-wage, low-skilled jobs among vulnerable populations (e.g., low-educated) (Presser, 2003a). On the one hand, highly educated and highskilled workers might work long hours to remain competitive in the globalized labor market (Kalleberg, 2013). But low-skilled workers can also work long hours, for example to compensate for the low hourly wage in order to make ends meet (Golden, 2015; Kalleberg, 2013). On the other hand, highly-educated employees may choose to underwork (i.e., part-time jobs) to balance work and family demands (e.g., taking care of young children), even if high-skilled workers especially women - have better chances to work full time (Pettit \& Hook, 2009). But low-skilled workers may underwork involuntarily, because they are not able to find full-time jobs despite the need to making ends meet. Our study examines this polarizing phenomenon by focusing on different work typologies across parents' gender and socioeconomic groups.

Second, we contribute to the work-family literature by adopting a cross-national approach to parental work, using detailed data from working mothers and fathers across 29 European countries. While some recent studies have compared countries regarding parents' work schedules (Täht \& Mills, 2016), they tended to focus on a small sample of countries from Western Europe or countries with liberal-oriented social policy regimes. In contrast, our study compared 29 
European countries representing different welfare state regimes. Building upon the welfare regimes typology, first developed by Esping-Andersen $(1990,1999)$ and expanded by the gender-family regimes typology (Lewis, 2009), we focused on five welfare state typologies across Europe, including Social Democratic (e.g., Denmark, Sweden), Corporatist (e.g., France, Germany), Liberal (e.g., Ireland, UK), Southern European (e.g., Italy, Spain), and CentralEastern European (e.g., Hungary, Poland). These five welfare regimes represent different social, political, and cultural contexts (e.g. gender relations) that shape the structure and operation of the labor market, which in turn may dictate any (positive or negative) impact of working nonstandard schedules, overworking ( $>=45$ hours per week) or underworking $(=<25$ hours per week) on the health and wellbeing of the families and children. The welfare state is intended to temper the harshness of capitalism so that different dosages of welfare (or de-commodification) provide different levels of protection to workers and working parents (Garfinkel, Rainwater \& Smeeding, 2010). While our data do not allow for causal claims, it provides new evidence on how parental work schedules and hours vary across welfare regimes over recent years.

Third, the present study used recent data covering trends in the type and hours of parental work, including three time points $(2005,2010,2015)$. While we cannot disentangle the causal effect of the economic crisis (the 2008 Great Recession) on changing working patterns, our data captured well three relevant economic points, including 2005 (pre-crisis), 2010 (recession) and

2015 (post-crisis). Hence, our study may shed some light on questions such as: Has the economic crisis led to changes in working patterns, and if so, are the changes differ by welfare states?

\section{PREVIOUS SCHOLARSHIP AND BACKGROUND}

Our study looks at two domains of parental work: (i) nonstandard work schedules (i.e., timing of work) and (ii) work hours (dividing it between 'short' and 'long' working hours). The literature on cross-national variations in paid work is extensive, including examining issues 
related to precarious employment, job insecurity and precarious conditions (e.g., Gallie, Felstead, Green \& Inanc, 2017; Kalleberg, 2018), work-family balance (e.g., Ruppaner \& Huffman, 2014), skill-based differences in working conditions (e.g., Oesch \& Rodriguez-Menes, 2010), and atypical employment (Kalleberg, 2018). This scholarship suggests that, after accounting for individual-level characteristics, welfare regimes matter to explaining labor market outcomes (e.g., the type of work, the work hours). Recent growing trends in the practice of precarious employment calls for more research to understand this phenomenon, particularly with a comparative lens. Focusing on parental work schedule and hours is critical to understand individuals' well-being, family life, and intergenerational equality in this globalized society.

The first measure that we examined, nonstandard work schedules, refers to hours that occur outside standard working hours. In her seminal work, Presser (2003a) defines nonstandard work schedules as hours occur outside of the 9am to 5pm daytime shift or irregular (e.g., changing from daytime to non-daytime hours from week to week, or on calls). Previous studies have shown that such schedules matter to the well-being of families and children and oftentimes in an adverse manner (Li et al., 2014). Thus far, most existing studies have analyzed samples from a single country, and only a few used multi-country data to examine the association between parental work schedules and the well-being of the family and the children (i.e., Täht \& Mills, 2016: comparing the Netherlands and the United States; Presser, Gornick \& Parashar, 2008: comparing 12 European countries using 2005 Eurostat; Tammelin, Malinen, Rönkä \& Venhoef, 2017: comparing Finland, the Netherlands, and the United Kingdom). For example, using descriptive information from 2005 Eurostat for 12 countries, Presser et al. (2008) found that weekday nonstandard work schedule varied widely across countries in 2005 , from $15 \%$ in Luxembourg (a Corporatist welfare state) to $30 \%$ in the United Kingdom (a Liberal welfare state) and weekend work ranged from $10 \%$ in Sweden (Social Democratic) to $34 \%$ in Italy (Southern European). 
Furthermore, Presser et al. (2008) found that gender gaps in some countries were stronger (Austria, US, UK) compared to other countries such as Finland. For example, men and women had an equal likelihood of working at nonstandard hours in the Social Democratic countries, whereas men were generally more likely than women to work nonstandard hours in the Liberal welfare state. However, married mothers with young children in the United States and United Kingdom, where childcare services tend to be limited and expensive during nonstandard hours, were more likely than mothers in other countries to work at nonstandard schedules (Presser et al., 2008). Additionally, nonstandard work schedules were found to be more prevalent among disadvantaged groups (e.g., low-skilled and those working in the service sector), at least in the Liberal welfare state such as the United States (Presser, 2003a). Nevertheless, the literature has omitted a welfare state framework to account for the intersection of gender and socioeconomic position in understanding parental work schedule phenomenon. Welfare regimes might differ in their labor market protection and support for parents of different social backgrounds, and this may lead to cross-national differences in gender and socioeconomic gaps on nonstandard work schedules. Our study fills this knowledge gap by using a welfare state framework with a large number of countries.

The second domain of parental work that we considered is the number of work hours. We focused on 'long' and 'short' work hours as these forms of paid work hours are often associated with forms of 'atypical employment' (e.g., Hevenstone, 2010; Kalleberg, 2018). Studies found that women disproportionately worked shorter hours (e.g., part-time), especially in countries like the Netherlands, UK or Germany, with a strong tradition of promoting part-time jobs for the purpose of balancing the work and family demands (Lewis, 2009). Part-time work, however, was much less common in countries with dual-earner/dual-carer models, such as Social Democratic countries, with high levels of gender equality (Esping-Andersen, Boertien, Bonke \& Gracia, 2013). Countries with less protective welfare regimes, such as Liberal regimes or Southern 
European countries, tended to combine both short- and long-hours (OECD, 2019a). Research looking at trends in parents' short and long hours often used data prior to the 2008 Great Recession, and no systematic examination has been done of the patterns of short/long hours by gender and socioeconomic status across welfare regimes (Hevenstone, 2010; Jacobs \& Gerson, 2001). Labor demand and supply are likely to shift during an economic recession. Low-skilled and low-wage workers are likely to be the first fired during an economic recession but the last to be hired upon economic rebound. Employers may also cut down labor costs by hiring part-time instead of full-time employees who may be involuntarily subject to precarious, unpredictable schedules and hours. Working parents, particularly those of disadvantaged backgrounds, may thus respond to changes in labor demand during recession by taking up jobs with precarity. Countries take different austerity measures to dampen the adverse impact of the recession and hence how work patterns change during and post-recession may partly depend on welfare state.

\subsection{Welfare Regimes Typology}

In this study, we focused on five welfare regimes across Europe capturing different policy, cultural and labor market contexts: Social Democratic, Corporatist, Liberal, Southern European (SE), and Central-East European (CEE), building upon conceptual frameworks on welfare, work-family and gender regime typologies (Esping-Andersen, 1999; Ferragina \& Seeleib-Kaiser, 2011; Lewis, 2009).

Scandinavian countries, labeled as the Social Democratic (SD) regime, have historically and culturally emphasized equality and social citizenship, with high levels of decommodification (Esping-Andersen, 1990). Despite recent trends toward de-universalization during the past decade (van Kersbergen \& Kraft, 2017), welfare benefits in Social Democratic regimes still promote a strong sense of solidarity and loyalty among its people to the welfare state (Hemerijck, 2017). The SD regime also endorses gender equality, with the aim to maximize equal labor force participation for both men and women. Hence, the gender gap in employment 
opportunities (including hours) and wages is minimized, compared to other welfare states in Europe (Esping-Andersen et al., 2013; Lewis, 2009).

The Corporatist welfare state, sometimes labeled as "conservative welfare state," tends to tie the welfare benefits to prior earnings and work status, although put less emphasis on free market efficiency than the Liberal regime (Esping-Andersen, 1999). Consequently, welfare benefits often preserve the social status (defined by earnings and work status). Due to the historical influence of the church, the Corporatist welfare state is also more strongly committed to the preservation of the traditional family structure (i.e., married two-parent families) and the male breadwinner model. The Corporatist welfare regime thus favors a gender ideology (norm) that deems the labor force participation of mothers with young children as inappropriate in larger society and among employers (Lewis, 2009). Some countries in this cluster, however, have implemented changes in family policy. In 2007, Germany underwent a drastic reform of family policy to promote the dual-earner family model and greater labor force participation of mothers with dependent children (e.g., substantial increases in state-owned daycare centers with low fees for young children; paid paternal and maternal leaves in the first year of a newborn). While countries like Germany have recently increased their maternal employment rates (by 7 percentage points from 2000 to $66 \%$ in 2012) (Meyer, 2016), the Corporatist regime is still linked to a more traditional male breadwinner model.

The Liberal welfare state is characterized by its reliance on the efficiency and effectiveness of the free market and it generally relies on individuals and families to meet their needs (Gornick \& Meyers, 2003). The Liberal welfare state follows the "poor law" model whereby welfare benefits are means-tested and are provided only for the income poor, creating a "residual" welfare state. In the Liberal welfare state, because of low and restricted welfare benefits as well as limited family-work reconciliation policies, maternal employment is comparatively high, but with significant gender wage gaps. For example, in the United States, 
when the Equal Pay Act was passed in 1963, women made only 59 cents on the dollar of a man made, and that figure rose to 82 cents by 2016 (U.S. Bureau of Labor Statistics, 2017). Similarly, in the United Kingdom, the gap was 50 cents on the pound back in 1970 and has since reduced to 83 cents by 2016 (OECD, 2019b). The gender wage gap was considerably lower in countries considered as social democratic welfare state such as Denmark and Norway (2019b).

The Southern European (SE) welfare regime is characterized by family-oriented welfare solidarity. Mothers are charged with childcare tasks, which contributes to low maternal employment rates in Southern Europe compared to other welfare states (Gracia \& EspingAndersen, 2015). For example, both Italy and Spain provide limited support (e.g., parental leave) for working mothers and fathers to balance paid work with family life, which explains the high incidence of male-breadwinner couples and part-time employment among mothers in both countries (Del Boca \& Wetzels, 2007; Esping-Andersen et al., 2013; Gracia \& Kalmijn, 2016; Jurado-Guerrero \& Naldini, 2018). In this respect, Southern European regimes share a similarity with the Corporatist welfare regime like Germany. However, what distinguishes these two types of welfare regimes is that the Corporatist welfare state generally provides more family support (e.g., extended periods of maternity and paternity leave), whereas the Southern European regime generally lack policies promoting universal support to equalize opportunities across families with children, contributing to elevated degrees of social inequality (e.g., Hemericjk et al., 2017).

The Central-Eastern European (CEE) cluster represents a diverse group of postcommunist European countries that were under the umbrella of the Soviet Union before 1989. Despite significant variations in social policies, universalism, and labor markets (Fenger, 2007), all countries in the CEE cluster have experienced some forms of transitions from a socialist to a free-market economy. The former-USSR ideology (e.g., Latvia, Letonia) endorses full employment and heavily subsidizes housing, education, and health care (Fenger, 2007). To survive economically after the separation from the USSR, many of the post-communist European 
countries (e.g., Czech Republic, Hungary, Poland) followed more of the free-market ideology to promote economic prosperity; these countries tend to have a residual welfare state with limited support for working parents (Fenger, 2007). Heterogeneity exists among this cluster, as some countries showed faster economic growth (e.g., Czech Republic, Poland) than others (e.g., Estonia, Romania). Still, the CEE cluster allows us to compare countries sharing similar economic trajectories with other European welfare regimes.

\subsection{Research Hypotheses}

Welfare Regime Differences: We anticipated that parents in Social Democratic regimes would show low levels of nonstandard work schedules, where the welfare state provides active job regulation for work-life balance. At the other extreme, in Liberal, SE, and CEE welfare regimes, work pressures and de-regulation in the labor market would lead parents to be more likely to work nonstandard schedules required by the $24 / 7$ and service economy. Countries categorized as a Corporatist would fall in between the above two opposing welfare regimes, as these countries have strong sectorial regulations, yet policies in Corporatist countries are less supportive of parental work choices (e.g., work hours) than in Social Democratic countries. As for overworking ( $>=45$ hours per week), we expected parents in Liberal, SE, and CEE countries to disproportionately engage in long work hours, compared to those in countries with high costs and strict regulations for long work hours (e.g., Corporatist and Social Democratic welfare regimes). Regarding underworking ( $=<25$ hours per week), we expected parents in the Social Democratic welfare regime to be less likely to underwork, as full-time employment is promoted for both mothers and fathers to achieve gender equality, compared to parents in other welfare regimes that tend to have institutionalized support for part-time employment among mothers (e.g., Corporatist) or to those in welfare regimes with more labor market de-regulation (e.g., Liberal, SE, and CEE countries). 
H-1. Parental nonstandard work schedules and underwork would be the least common in Social Democratic countries; overwork would be the least common in the Social Democratic regime followed by the Corporatist regime, and; all these work patterns would be the most common in the Liberal, SE, and CEE welfare regimes.

Gender Differences: Built upon previous theories and research on gender differences in employment and work characteristics (Presser, 2003b), we expected that fathers would be more likely than mothers to work nonstandard schedules and to overwork, while mothers would be more likely than fathers to underwork. Previous studies also showed that our five welfare regimes differ strongly in terms of gender equality in employment (Lewis, 2009). Gender differences in nonstandard work schedules, overworking and underworking would be weaker in the Social Democratic welfare regime than in the other four welfare regimes, as public policy and cultural norms in the former promote greater gender equality via labor market policies and work-family support, compared to the other four welfare regimes.

H-2. Compared to mothers, fathers would be more likely to work nonstandard schedules and to overwork and less likely to underwork, and, such gender differences would be smaller in the Social Democratic regime than elsewhere.

Educational Differences: Following previous research, we expected parental work (nonstandard schedules, overworking, and underworking) to be patterned by parents' level of education (Presser, 2003a). Given most workers complete their education before they enter the labor market, we used education instead of income or occupation as a proxy for socioeconomic status to reduce possible reverse causality. We argued that individuals with high levels of education would be in a relatively advantaged position to choose their own preferred work schedules and hours, as they would be less likely to work at nonstandard schedules or to over- or underwork involuntarily. While high-educated individuals would tend to work at jobs that require long work hours, especially in some occupational sectors, the less educated might be more likely to involuntarily overwork to make ends meet (Kuhn \& Lozano, 2008; Presser et al., 2008). Hence, it is unclear whether education would be linked to differences in under- or 
overworking. Additionally, we expected that educational differences in nonstandard schedules, over-, and underworking would be less salient in the Social Democratic welfare regime, as this welfare regime is characterized by high redistributive policies with universal support for parents, compared to non-Social Democratic welfare regimes (Esping-Andersen, 1999; Gracia \& Ghysels, 2017). In contrast, we expected educational differences in work hours to be the most pronounced in Liberal countries, where social inequalities are relatively high due to weak labor market regulation to protect equalities in working conditions (Kalleberg, 2018; Narayan et al., 2018).

H-3. More educated parents would be less likely than their less-educated counterparts to work nonstandard schedules, but there would be no clear predictions in educational gaps regarding overworking and underworking; and educational differences in parental work would be lower in the Social Democratic regime than elsewhere.

Time trends: We anticipated changes in parental work patterns from 2005 to 2015 . The 2008 Great Recession brought rising levels of poverty and unemployment across industrialized countries (Ferrera \& Rhodes, 2013). In a context of economic crisis, parents might lose bargaining power. Thus, on the one hand, parents might increase their engagement in nonstandard, long or short working hours. On the other hand, working parents may be forced by employers to reduce work hours to save labor costs. We also anticipated different trends in the nature of parental nonstandard work schedules and work hours across welfare state regimes. Indeed, welfare states have adopted different employment regulation strategies after the recent economic crisis. For example, Scandinavian countries have kept quite high levels of universalism and work regulatory policies, as opposed to countries in Southern Europe, Liberal, and various post-communist countries, which have receded from active work protection (see Ferrera \& Rhodes, 2013). Therefore, the increase in nonstandard work schedules, overworking, and underworking would be stronger in countries with low working protection and high levels of labor market de-regulation policies (i.e., Liberal, SE, and CEE welfare states), compared to 
regimes that maintained comparatively high levels of job protection (Corporatist, Social Democratic).

H4. Parental nonstandard work schedules, over- and underworking would be more prevalent in 2010 and 2015, compared to 2005, but only within the Liberal, SE and CEE regimes.

\section{METHODS}

\subsection{Data}

We used data from the European Working Conditions Survey (EWCS). The EWCS has been since 1990 surveying a random sample of employees across European countries about their working conditions with face-to-face interviews. We analyzed 29 countries from the European Union (EU) with data collected for three waves: 2005, 2010 and 2015. On average, about 1,000 working parents with children younger than age 15 and living in the household in each wave were interviewed for each of these 29 EU countries. We clustered these countries into five welfare state categories discussed above and described in detail below.

\subsection{Measures}

Parental Work. We examined three dependent variables: (i) Nonstandard work schedules, defined as parents working at nonstandard work schedules if they answered yes to having "worked at shifts" (including evenings, nights, split shifts, rotating shifts) on the main job and/or having worked 3 or more times each month on Saturdays or on Sundays; (ii) Overworking, defined as weekly working hours of 45 or more following previous studies (Golden \& Gebreselassie, 2007; Kuhn \& Lozano, 2008; Reynolds, 2003) (in analyses not shown, we used the cutoff of 50 or more hours as overworking where the sample size was smaller, less than $10 \%$, despite obtained qualitatively similar results); (iii) Underworking, defined as weekly working hours of 25 or less following previous studies (Golden \& Gebreselassie, 2007; Kuhn \& Lozano, 2008; Reynolds, 2003) (in analyses not shown, we used the cutoff of 20 hours or fewer 
as underworking; again, sample size was much smaller, less than 10\%, despite obtaining qualitatively similar results as those reported here).

Welfare state. Considering historical and geographic proximity, we built upon EspingAndersen's welfare regime typologies $(1990,1999)$ and literature on gender-family regimes (Lewis, 2009) to categorize 29 European countries into five welfare state regimes: (1) Social Democratic (Denmark, Finland, Norway, and Sweden); (2) Corporatist (Austria, Belgium, France, Germany, Luxemburg, and Netherlands); (3) Liberal (Ireland and UK); (4) Southern European (SE) (Cyprus, Greece, Italy, Malta, Portugal, and Spain), and; (5) Central-Eastern European (CEE) (Bulgaria, Croatia, Czech Republic, Estonia, Hungary, Latvia, Lithuania, Poland, Romania, Slovakia, and Slovenia).

Demographic characteristics. We considered several important demographic characteristics that have been shown to be associated with parental work (Kalleberg, 2013; Presser, 2003), including parent's gender, age, education, number of children under the age of 15, earned income, and occupation. We followed the International Standard Classification of Education (ISCED 2011) to categorize educational level to be 'primary' (from no education to lower secondary education), 'secondary' (i.e., upper secondary and post-secondary), or 'tertiary' (i.e., first and advanced level of tertiary) (UNESCO Institute for Statistics, 2011). We used the question asked in the EWCS about the respondent's net monthly income on average from the primary job to define earned income. We then categorized earned income into four quartiles based on the sample distribution within each country with the first quartile representing the lowest income and the fourth quartile the highest income. We followed the International Standard Classification of Occupation (ISCO) to define three broad occupational categories: (1) managers or professionals, (2) clerks, sales, and administrative workers, and; (3) skilled and nonskilled manual and non-manual working classes. 


\subsection{Empirical Strategy}

We based our empirical models along the welfare state typologies. First, we conducted basic descriptive and bi-variate analyses. Second, we conducted multivariate logistic regression analyses, looking at welfare state differences in the prevalence of each of parental work patterns, controlling for sociodemographic variables described in the Measures section. Third, we estimated interaction effects of welfare state regime with (i) year of observation, (ii) gender, and (iii) education on the prevalence of parental work schedules and work hours.

\section{RESULTS}

\subsection{Descriptive Analyses}

Table 1 provides a summary of our analyzed variables across the five welfare state regimes. Mothers and fathers were in general equally represented in the sample, while the average age of these parents was in their late thirties, with about 1-2 children aged 14 or younger at home. One-third of the parents had achieved tertiary education, whereas the other half had at least secondary education. About $40 \%$ of parents held occupations at management and professional level, with another third of each working at occupations related to either services (e.g., clerks, care providers, sales) or manual/non-manual working class (e.g., craft, machine operators). Significant descriptive bivariate differences were observed in sociodemographic characteristics between welfare states, and many sociodemographic characteristics (e.g., gender, education, occupation, and income) were associated with various levels of nonstandard work schedules, and long or short work hours, but differently across welfare regimes. For example, we observed a greater educational and income inequality among parents in Liberal welfare state than those in Social Democratic welfare state (significant levels not shown, available upon request). These important welfare state differences justify the use of socioeconomic and demographic controls in the analyses. 
Table 1 also provides a descriptive overview of work patterns in the sampled parents from 2005 to 2015, separately by welfare state. In general, about one-third of parents with at least one child under the age of 15 had worked regularly at nonstandard schedules (e.g., evenings, nights, rotating or split shifts, or weekends). About a quarter of parents worked 45 or more hours per week (overworking), whereas a slightly more than $10 \%$ of the parents worked 25 or less hours per week (underworking). Notably, parents in the SE or CEE countries worked more often in nonstandard work schedules than parents in other welfare states, whereas parents in the SD welfare state were the least likely to work at such schedules. Furthermore, parents in SE or CEE regimes were more likely to be overworking, whereas parents in the Liberal or Corporatist welfare states were more likely to be underworking. In Figure A1 (Annexes), we present the unadjusted percentages of parents working at nonstandard schedules (Panel A), overworking (Panel B), and underworking (Panel C) by year, welfare state, and gender.

\subsection{Multivariate Analyses}

Table 2 presents the unstandardized coefficients with robust standard errors from the multivariate logistic regression for all three parental work measures, controlling for all sociodemographic variables detailed in the Measures section. These results were also presented in Figure 2, using predicted probabilities and confidence intervals at the $95 \%$ level.

\section{Main Effects}

Welfare state. As shown in Table 2, compared to parents in the SD welfare regime, parents in all other welfare states had a statistically significantly higher probability of working at nonstandard schedules. Compared to parents in the SD welfare regime, parents in the Liberal, SE, and CEE welfare regimes had a significantly higher probability of overworking, while parents in the Corporatist regime had a significantly lower probability of overworking $(p<0.01)$. Parents in the Corporatist, Liberal, and SE welfare regimes had a significantly higher probability of underworking than those in the SD welfare regime $(p<0.001)$. 
Period-Year. Results in Table 2 indicate that parents in the year 2015 had a significantly higher probability of working at nonstandard schedules than parents in $2005(p<0.05)$. In contrast, parents in 2010, compared to 2005, had a significantly lower probability of overworking $(p<0.001)$, as well as a significant dip in the percentage of underworking $(p<$ $0.01)$.

Parent gender. Results in Table 2 indicate that compared to fathers, mothers had a significantly higher probability of underworking $(B=1.19 ; p<0.001)$, and a lower probability working at nonstandard schedules $(B=-0.15 ; p<0.001)$ and overworking $(B=-0.91 ; p<0.001)$.

Parental education. As shown in Table 2, compared to parents with tertiary education, parents with primary or secondary education had a significantly higher probability of working nonstandard schedules and overworking $(p<0.001)$, but a significantly lower probability of underworking $(p<0.001)$.

\section{Interaction Effects}

Table 3 presents nine models estimating our three measures of parental work, using interaction effects of welfare state with (i) year (M-1, M-4, M-7), (ii) gender (M-2, M-5, M-8), and (iii) education (M-3, M-6, M-9). The analyses of Table 3 are supported graphically in Figure 2 by using predicted values with confidence intervals at the $95 \%$ level.

Welfare state by year. M-1 of Table 3 shows that parents in the Liberal welfare state had a significantly higher probability of working at nonstandard schedules in both 2010 and 2015 compared to parents in the SD $(p<0.01)$. Results shown in M-4 of Table 3 indicate that, compared to 2005, parents in the SD regime were significantly more likely to overwork in 2015 $(p<0.01)$. In contrast, compared to 2005, parents in the Liberal regime in 2010, parents in the SE regime in 2015, and parents in the CEE welfare regime in both 2010 and 2015 were significantly less likely to overwork. In M-7 column of Table 3, we observed a significantly increasing probability of underworking in the Liberal welfare state in 2010, in the SE welfare 
state in 2015, and the CEE welfare state in 2010, compared to their national counterparts in 2005.

Overall, Figure 3 presents the comparison in the probability of working at nonstandard schedules, overworking and underworking by welfare state and year and shows that among all welfare states, parents in the Liberal, SE, and CEE welfare states had a higher prevalence of working at nonstandard schedules and overworking; parents in the CEE welfare state had the highest prevalence of overworking, followed by those in the SE and Liberal welfare states, and; parents in the Liberal regime had the highest prevalence of underworking, followed by those in the Corporatist regime.

Welfare state by gender. Results in M-2 column of Table 3 revealed larger gender differences in working nonstandard schedules in the Corporatist, Liberal, and SE welfare states compared to that in the SD welfare state. Figure 3 and post-hoc test results (not shown, available upon request) showed that fathers in the SE welfare state had the highest probability of working nonstandard schedules, followed by fathers in the Liberal regime, across these five welfare states. Also, mothers in the CEE welfare state had the highest probability of working nonstandard schedules among all mothers throughout the five welfare states. In contrast, mothers in the Corporatist regime had the lowest probability of working at nonstandard schedules, followed by mothers in the SD regime. Regarding overworking, results shown in M-5 column of Table 3 indicate that mothers had a significantly lower probability than fathers of overworking in the SD welfare state $(b=-1.02, p<.001)$. The same gender difference holds true for the Liberal and CEE welfare states. However, mothers in the Liberal regime were significantly less likely $(b$ $=-0.83, p<.001)$ and mothers in the CEE regime were significantly more likely $(b=0.41, p<$ .001) than those in the SD welfare state to overwork. Finally, results shown in M-8 column of Table 3 indicate significantly larger gender differences in underworking in the Corporatist, Liberal, and SE welfare states, compared to the SD welfare state $(b=1.14, p<.001, b=1.40, p$ 
$<.001, \& b=-0.46, p<.05$, respectively). Figure 3 and post-hoc estimations (not shown, available upon request) indicated that mothers in the Liberal welfare state were significantly more likely to underwork than mothers in all other welfare states $(p<.001)$, closely followed by mothers in the Corporatist regime. By contrast, cross-welfare state differences in fathers' underworking were minor.

Welfare state by education. Results shown in M-3 column of Table 3 indicate that, compared to parents with tertiary education, parents with primary and secondary education were significantly more likely to work nonstandard schedules in the CEE welfare state, in relation to their counterparts in the SD welfare state. Figure 3 and post-hoc estimations (not shown, available upon request) indicated that, among those with primary education, parents in the Liberal, SE, and CEE regimes had a significantly higher probability of working nonstandard schedules than those in the SD and Corporatist regimes. Furthermore, parents in the SE and CEE welfare states had a significantly higher probability of working nonstandard schedules than those in the Liberal welfare states. In addition, among those with secondary education, parents in the SE and CEE welfare states had a significantly higher probability of working nonstandard schedules than parents in other welfare states, and parents in the Corporatist and Liberal welfare states had a significantly higher probability of working nonstandard schedules than those in the SD welfare state.

Results in M-6 of Table 3 showed that parents with primary education in the Corporatist regime had a significantly lower probability of overworking than their national counterparts with tertiary education, whereas parents with secondary education and parents with primary and secondary education were significantly more likely to overwork than their national counterparts with tertiary education. Parents in the Liberal welfare state had a similar probability of overworking no matter their education level. Overall, in the SE welfare state, parents with primary education had the highest probability of overworking, with significant differences 
between all three educational groups. In the CEE regime, parents with primary and secondary education had a similar probability of overworking, and this probability was significantly higher than that of their CEE counterparts with tertiary education. Figure 3 and post-hoc estimations (results not shown, available upon request) further indicated that, among parents with primary education, the highest probability of overworking was in the SE and CEE welfare states, and the lowest in the Corporatist regime. Among parents with secondary education, those in the Liberal, SE, and CEE welfare states had a significantly higher probability of overworking than those in the SD and Corporatist welfare states. Finally, parents with secondary education in the CEE welfare state had the highest probability of overworking, followed by parents with the same educational level in the SE and then in the Liberal welfare states.

Results in M-9 column of Table 3 revealed insignificant differences in the likelihood of underworking between parents with primary and secondary education and those with tertiary education in the SD, Corporatist, and Liberal regimes. Parents with tertiary education in the SE and CEE welfare states were significantly more likely to underwork than their respective counterparts. Figure 3 and additional post-hoc estimations (results not shown, available upon request) showed that parents with primary and secondary education in the Liberal welfare state had the highest probability of underworking, followed by their respective counterparts from the Corporatist regime, and then by those in the SE regime. Finally, parents with primary education in the Corporatist welfare state were significantly more likely to underwork than their counterparts with primary education in the SD, SE, and CEE welfare states.

\subsection{Sociodemographic Variables}

Results in Table 2 showed the importance of demographic characteristics to the probability of parents working at nonstandard schedules, overworking, or underworking. Older parents were less likely to work at nonstandard schedules but more likely to underwork than their younger counterparts. Having more children under the age of 15 was significantly positively 
associated with either overwork or underwork. Parental income and occupation were important parameters for parental work, yet interestingly not all measures of socioeconomic position operated in the same way. While highly educated parents, and high-income parents with managerial and professional jobs were significantly less likely to work nonstandard schedules, parents with the highest income (fourth quartile) were significantly more likely to overwork than their lower income counterparts. Likewise, parents with income in the first to third quartiles versus those in the fourth quartile were significantly more likely to underwork. Yet, parents with non-professional, non-managerial occupations were significantly less likely to underwork than their corresponding counterparts. These mixed results suggest that social and demographic contexts reveal complex mechanisms for understanding the advantages and disadvantages in work patterns due to parental resources and conditions.

\subsection{Robustness Checks}

We conducted some additional robustness checks to gauge the reliability of our estimates reported above. First, in analyses not shown (available upon request) we estimated the association of individual-level variables (i.e. gender, education) with our three parental work measures, using country-year fixed effects that accounted for potential unobserved heterogeneity within country and year. The estimates from these fixed effects models were consistent with those reported above. Second, we used the marginal effects reported in Table 3 to predict our parental work measures for the 29 countries of the sample separately, as presented in Figure A2 (Annexes), to address the level of within-cluster variations in parental work. Results showed consistent patterns within clusters, although with some variations in the probability of nonstandard work schedules in the CEE regime and underworking in the Corporatist regime. For example, we found that Greece had the highest probability of parents working at nonstandard schedules. And, both Greece and Romania had the highest probability of overworking, whereas the Netherlands had the highest probability of parents underworking. In contrast, parents in 
Denmark and Netherlands had the lowest probability of working at nonstandard schedules, parents in Luxemburg, Finland, and Belgium had the lowest probability of overworking, and parents in Estonia and Sweden had the lowest probability of underworking.

\section{DISCUSSION}

Using the EWCS from 2005 to 2015, we examined three working patterns (nonstandard work schedules, overworking, and underworking) among parents with children younger than age 15 across 29 European countries. We found substantial variations in these work patterns at both the welfare state level and across time, gender, and education.

Nonstandard work schedules. Our results showed an increasing trend in nonstandard work schedules in Europe from 2005 to 2015, especially in the Liberal welfare state. Working nonstandard schedules was most common in the SE and CEE countries, followed by the Liberal welfare state and then by the Corporatist welfare state. The SD welfare state stood out as having the lowest prevalence of nonstandard work schedules among all five welfare states. On average, more than one-third of parents with children under the age of 15 worked at schedules that are considered to be nonstandard or unsociable (e.g., evenings, nights, weekends, or variable) between 2005 and 2015, and this was particularly pronounced among parents who had low education, worked in the service sector, and/or had low incomes - as many as half of these parents worked nonstandard schedules. Fathers were more likely to work nonstandard schedules, compared to mothers, yet these differences were mostly concentrated within the Liberal and SE regimes. Finally, educational inequalities in working unsociable hours generally applied to all welfare states, but particularly to the CEE and SE regimes.

Overworking. Between 2005 and 2015, across all European countries, more than onefifth of parents worked 45 or more hours per week, being this prevalence highest in the SE and CEE welfare regimes, followed by the Liberal regime. Parents with primary or secondary 
education, but also those with incomes at the top (fourth) quartile, had a disproportionate tendency to overwork. Yet, there were clear cross-welfare state variations in this educational gradient. For example, in the SE and CEE welfare states parents with primary and secondary education were significantly more likely to overwork than those with tertiary education, while the opposite was true for parents in the Corporatist welfare state. In contrast, education made no difference in the probability of overworking in the Liberal welfare state. Finally, mothers were clearly less likely than fathers to overwork, with large differences in all welfare states, yet these gaps were mostly pronounced in the Liberal regime, followed by the SE regime.

Underworking. Underworking was clearly less prevalent than nonstandard work schedules and overworking, representing only one-eighth of our sample. Yet, we observed clear variations by welfare state, gender, and education in the prevalence of underworking. Mothers were more likely to underwork than fathers, particularly in the Liberal and Corporatist welfare states. Results comparing parents with similar educational level across five welfare states further suggest that parents with each educational level (primary, secondary, and tertiary) in the Liberal welfare state were the most likely to underwork among all five welfare states. Also, parents with the lowest income quintile were most likely to underwork and this likelihood decreased with the increase in each income quintile. However, we found that parents with occupations other than managers and professionals were less likely to underwork than their counterparts with managers and professional occupation. Overall, findings on underworking underscore the complexities of the intersections between individual characteristics, welfare state, and labor market in our 29 European countries of study.

\section{LIMITATIONS}

This study presents some limitations that need to be stressed. First, although we examined three key aspects of parental work that carried important implication to the prevalence of precarious 
employment, our understanding of precarious employment would be strengthened by examining indicators such as unpredictability (e.g., on-call hours) and insecurity (e.g., lack of work contract, lack of job-associated benefits, low wages).

Second, we framed our examination of parental work using welfare state regimes, showing that macro-level factors were associated with strong variations in parental work. To further understand these micro-macro processes, future studies would benefit from a multilevel approach whereby country-level variations are considered to disentangle the effects of macrolevel contexts from those of micro-level contexts.

Third, although the data on three years of observation $(2005,2010,2015)$ provided a meaningful glance at the potential impact of Great Recession of 2008 on the working lives of parents, the three time periods did not provide enough data points to provide both the pre- and post-estimations. Fourth, future studies could address these cross-country differences by applying a qualitative lens such as that developed in recent qualitative typologies at the organizational level (Kossek, Rosokha \& Leana, 2019) to complement the quantitative approach.

\section{CONCLUSIONS}

Our findings highlight two types of potential labor risks in today's globalized, digitalized and service-based economy: income and time poverty. Parents with disadvantaged backgrounds (e.g., less-skilled workers) were more likely to work nonstandard schedules, a shift that has been shown as unsociable, unpredictable, and precarious (Presser, 2003a). Also, parents with only primary or secondary education were more likely to overwork than parents with tertiary education, thus being time poor. As for gender, we found that fathers were more likely than mothers to overwork and work nonstandard schedules and thus being time poor, whereas mothers were more vulnerable to be income poor due to their high likelihood of underworking. These findings are particularly relevant regarding inequalities in nonstandard work hours and 
overworking, as these working patterns are associated with poorer health and well-being among parents and children, including less close parent-child relations and adverse child developmental outcomes (e.g., socio-emotional and health concerns) (Gracia \& Garcia-Roman, 2018; Gracia \& Kalmijn, 2016; Han, 2008; Kaiser, Li \& Pollmann-Schult, 2019; Johnson, Li, Kendall, Strazdins \& Jacoby, 2013; Li et al., 2014) and overweight and obesity (Li et al., 2017; Li, Kaiser, Pollmann-Schult \& Strazdins, 2019).

Our study shows that parental work schedules and hours differ remarkably across different macro-level contexts. Our results demonstrate that parents in the SD welfare state had the lowest likelihood of working at nonstandard schedules, overworking, or underworking, compared to parents in all other welfare states. This difference may reflect stronger social protection for workers and families through working time regulations and family-friendly policies in the SD welfare state (e.g., affordable child care). By contrast, in the SE and CEE regimes, without a strong universal protection to tackle social inequalities, educational inequalities in nonstandard work schedules and overworking were salient. Yet, it is worth noting the similar probabilities of overworking and underworking for parents in the Liberal welfare states, irrespective of their educational level. This does not mean that social inequalities is unrelated with the working conditions of under- and overworking parents in more marketoriented societies. To the contrary, less educated parents might be more likely to confront with constrained or limited resources than their more educated counterparts in the Liberal welfare state. For example, parents with low education tend to be required to take on more work hours to compensate for their low wages in order to make ends meet, or being often forced to involuntarily taking fewer work hours due to the limited work opportunities afforded to lessskilled workers in market-oriented economies (Kalleberg, 2018).

Our ultimate goal in examining parental work patterns across welfare state was to provide new rich evidence on the potential impact of work conditions in the $24 / 7$ global economy on both 
parents and children, including childcare resources. As illustrated in recent scholarship, the SD welfare state, as represented for example by Finland, goes one step further to provide early childhood care and education for parents who work unsociable hours, providing accessible child care at universal standards, which would protect both family life and child well-being (Rönkä et al., 2017). Could these differences in parental work conditions and family support systems account for high-quality family relations and child well-being across different working families in different welfare states? Our understanding of the importance of parental work to the wellbeing of families and children across policy contexts can only be enhanced from a cross-national longitudinal research. Our answers to these inquiries would provide solid empirical evidence to inform labor market and family policies at both the national and global level with aims to promote the well-being of families and children. 


\section{REFERENCES}

Del Boca, D., \& Wetzels, C. (Eds.). (2007). Social policies, labour markets and motherhood: A comparative analysis of European countries. Cambridge, UK: Cambridge University Press.

Esping-Andersen, G. (1990). The three worlds of welfare capitalism. Princeton, New Jersey: Princeton University Press.

Esping-Andersen, G. (1999). Social foundations of postindustrial economies. New York: Oxford University Press.

Esping-Andersen, G., Boertien, D., Bonke, J., \& Gracia, P. (2013). Couple specialization in multiple equilibria. European Sociological Review, 29(6), 1280-1294.

Fenger, H. J. M. (2007). Welfare regimes in Central and Eastern Europe: Incorporating postCommunist countries in a welfare regime typology. Contemporary Issues and Ideas in Social Sciences, 3(2), 1-30.

Ferragina, E., \& Seeleib-Kaiser, M. (2011). Thematic Review: Welfare regime debate: past, present, futures? Policy \& Politics, 39(4), 583-611.

Ferrera, M., \& Rhodes, M. (2013). Recasting European welfare states. London: Routledge.

Gallie, D., Felstead, A., Green, F., \& Inanc, H. (2017). The hidden face of job insecurity. Work, Employment and Society, 31(1), 36-53.

Garfinkel, I., Rainwater, L., \& Smeeding, T. (2010). Wealth and welfare states: Is America a laggard or leader? New York: Oxford University Press.

Golden, L. (2015). Irregular work schedules and its consequences. EPI Briefing Paper \#394. Washington, DC: Economic Policy Institute. Retrieved from https://www.epi.org/files/pdf/82524.pdf

Golden, L., \& Gebreselassie, T. (2007). Overemployment mismatches: The preference for fewer work hours. Monthly Labor Review, April, 18-37.

Gornick, J. C., \& Meyers, M. K. (2003). Families that work: Policies for reconciling parenthood and employment. New York: Russell Sage Foundation.

Gracia, P. \& Esping-Andersen, G. (2015). Fathers' child care time and mothers' paid work: A cross-national study of Denmark, Spain, and the United Kingdom. Family Science, 6(1) $270-281$.

Gracia, P., \& García-Román, J. (2018). Child and adolescent developmental activities and time use in Spain: The gendered role of parents' work schedules and education levels. European Sociological Review, 34(5), 518-538. 
Gracia, P. \& Ghysels, J. (2017). Educational inequalities in parental care time: Cross-national evidence from Belgium, Britain, Denmark, and Spain. Social Science Research, 63(2), 166180.

Gracia, P., \& Kalmijn, M. (2016). Parents' family time and work schedules: The split-shift schedule in Spain. Journal of Marriage and Family, 78(2), 401-415.

Han (2008). Shift work and child behavioral outcomes. Work, Employment, and Society, 22(1), 67-87.

Hemerijck, A. (Ed.). (2017). The uses of social investment. Oxford, UK: Oxford University Press.

Hevenstone, D. (2010). National context and atypical employment. International Sociology, 25(3), 315-347.

Jacobs, J. A., \& Gerson, K. (2001). Overworked individuals or overworked families? Explaining trends in work, leisure, and family time. Work and occupations, 28(1), 40-63.

Johnson, S., Li, J., Kendall, G., Strazdins, L., \& Jacoby, P. (2013). Mothers' and fathers' work hours, child gender and behavior in middle childhood. Journal of Marriage and Family, 75, 56-74.

Jurado-Guerrero, T. \& Naldini, M. (2018). Child and family policy in Southern Europe. In G. B. Eydal \& T. Rostgaard (eds.), Handbook of Family Policy (pp. 209-222). Cheltenham, UK: Edward Elgar Publishing.

Kaiser, T., Li, J., \& Pollmann-Schult, M. (2019). Evening and night work schedules and children's social and emotional well-being. Community, Work \& Family, 22(2), 167-182. doi: $10.1080 / 13668803.2017 .1404443$

Kalleberg, A. (2013). Good jobs, bad jobs: The rise of polarized and precarious employment systems in the United States, 1070s-2000s. New York, NY: Russell Sage Foundation.

Kalleberg, A. (2018). Precarious lives: Job insecurity and well-being in rich democracies. UK: Polity Press.

Kossek, E. E., Rosokha, L. M., \& Leana, C. (2019). Work schedule patching in health care: Exploring implementation approaches. Work and Occupations, doi: $10.1177 / 0730888419841101$

Kuhn, P., \& Lozano, F. (2008). The expanding workweek? Understanding trends in long work hours among U.S. men, 1979-2004. NBER Working Paper No. 11895. Retrieved from https://www.nber.org/papers/w11895

Lewis, J. (2009). Work-family balance, gender and policy. Cheltenham, UK: Edward Elgar. 
Li, J., Johnson, S., Han, W-J., Andrews, S., Dockery, M., Kendall, G., \& Strazdins, L. (2014). Parents' nonstandard work and child wellbeing: A critical review of the literature. Journal of Primary Prevention, 35(1), 53-73. doi: 10.1007/s10935-013-0318-z

Li, J., Akaliyski, P., Schäfer, J., Kendall, G., Oddy, W. H., Stanley, F., \& Strazdins, L. (2017). Non-linear relationship between maternal work hours and child body weight: Evidence from the Western Australian Pregnancy Cohort (Raine) Study. Social Science \& Medicine, $186,52-60$.

Li, J., Kaiser, T., Pollmann-Schult, M., \& Strazdins, L. (2019). Long work hours of mothers and fathers are linked to increased risk for overweight and obesity among preschool children: Longitudinal evidence from Germany. Journal of Epidemiology and Community Health, 0, 1-7. doi:10.1136/jech-2018-211132.

Meyer, S. C. (2016). Maternal employment and childhood overweight in Germany. Economics and Human Biology, 23, 84-102.

Narayan, A., Van der Weide, R., Cojocaru, A., Lakner, C., Redaelli, S., Mahler, D. G., Ramasubbaiah, R. G. N., \& Thewissen, S. (2018). Fair progress? Economic mobility across generations around the world. Washington, DC: World Bank.

OECD (2019a). Family database. Retrieved from http://www.oecd.org/els/soc/LMF_1_6_Gender_differences_in_employment_outcomes.xls $\mathrm{X}$

OECD (2019b). Gender wage gap (indicator). doi: 10.1787/7cee77aa-en (Accessed on 10 April 2019)

Oesch, D., \& Rodríguez Menés, J. (2010). Upgrading or polarization? Occupational change in Britain, Germany, Spain and Switzerland, 1990-2008. Socio-Economic Review, 9(3), 503531.

Pettit, B., \& Hook, J. L. (2009). Gendered tradeoffs: Women, family, and workplace inequality in twenty-one countries. New York: Russell Sage Foundation.

Presser, H. B. (2003a). Working in a 24/7 economy: Challenges for American families. New York: Russell Sage Foundation.

Presser, H. B. (2003b). Race-ethnic and gender differences in nonstandard work shifts. Work and Occupations, 30(4), 412-439.

Presser, H. B., Gornick, J. C., \& Parashar, S. (2008). Gender and nonstandard work hours in 12 European countries. Monthly Labor Review, 131, 83-103.

Reynolds, J. (2003). You can't always get the hours you want: Mismatches between actual and preferred work hours in the U.S.. Social Forces, 81(4), 1171-1199. 
Rönkä, A., Malinen,K., Metsäpelto, R-L., Laakso, M-L., Sevón, E., \& Verhoef-van Dorp, M. (2017). Parental working time patterns and children's socioemotional wellbeing: Comparing working parents in Finland, the United Kingdom, and the Netherlands. Children and Youth Services Review, 76, 133-141.

Ruppanner, L., \& Huffman, M. L. (2014). Blurred boundaries: Gender and work-family interference in cross-national context. Work and Occupations, 41(2), 210-236.

Täht, K., \& Mills, M. (2016). Out of time: The consequences of non-standard employment schedules for family cohesion. Netherlands: Springer Netherlands. doi: 10.1007/978-94017-7402-4

Tammelin, M., Malinen, K., Rönkä, A., \& Verhoef, M. (2017). Work schedules and work-family conflict among dual earners in Finland, the Netherlands, and the United Kingdom. Journal of Family Issues, 38(1), 3-24.

UNESCO Institute for Statistics (2011). International Standard Classification of Education, ISCED 2011. Retrieved from http://uis.unesco.org/sites/default/files/documents/international-standard-classification-ofeducation-isced-2011-en.pdf

U.S. Bureau of Labor Statistics (2017). Highlights of women's earnings in 2016. BLS Reports. Available at https://www.bls.gov/opub/reports/womens-earnings/2016/pdf/home.pdf

Van Kersbergen, K., \& Kraft, J. (2017). De-universalization and selective social investment in Scandinavia? In A. Hemerijck (ed.), The Uses of social investment (pp. 216-226). Oxford, UK: Oxford University Press. 
Table 1. Sociodemographic Characteristics of the EWCS Married-Couple Samples with Children Less Than Age 15 by Welfare State Regime, 2005-2015

\begin{tabular}{|c|c|c|c|c|c|c|}
\hline & \multirow[b]{2}{*}{ Total } & \multicolumn{5}{|c|}{ Welfare Regimes } \\
\hline & & $\begin{array}{c}\text { Social } \\
\text { Democratic }\end{array}$ & $\begin{array}{l}\text { Corporativist } \\
\text { Regime }\end{array}$ & $\begin{array}{l}\text { Liberal } \\
\text { Regime }\end{array}$ & $\begin{array}{l}\text { Southern } \\
\text { European }\end{array}$ & $\begin{array}{c}\text { Central-Eastern } \\
\text { Europe }\end{array}$ \\
\hline Mothers (vs. fathers) (\%) & 48.20 & 48.81 & 48.09 & 45.16 & 44.88 & 50.88 \\
\hline Age & $38.41(6.89)$ & $39.45(7.08)$ & $38.65(6.82)$ & $39.03(7.15)$ & $39.36(6.87)$ & $37.02(6.60)$ \\
\hline \multicolumn{7}{|l|}{ Education (\%) } \\
\hline Primary & 18.01 & 6.62 & 17.77 & 24.48 & 31.69 & 12.61 \\
\hline Secondary & 48.34 & 42.32 & 44.85 & 37.52 & 41.73 & 60.61 \\
\hline Tertiary & 33.65 & 51.06 & 37.38 & 38.00 & 26.58 & 26.78 \\
\hline \multicolumn{7}{|l|}{ Income quarter $(\%)$} \\
\hline Bottom & 22.01 & 17.27 & 23.83 & 21.80 & 21.56 & 23.09 \\
\hline Second & 24.22 & 25.38 & 24.06 & 23.59 & 23.74 & 24.18 \\
\hline Third & 26.25 & 28.29 & 25.11 & 23.21 & 27.44 & 26.28 \\
\hline Fourth & 27.52 & 29.05 & 27.00 & 31.39 & 27.26 & 26.45 \\
\hline Number of children under 15 & $1.62(0.74)$ & $1.78(0.80)$ & $1.69(0.77)$ & $1.81(0.86)$ & $1.51(0.66)$ & $1.50(0.68)$ \\
\hline \multicolumn{7}{|l|}{ Occupation $(\%)$} \\
\hline Managers \& Professionals & 40.36 & 56.90 & 42.32 & 50.46 & 32.12 & 34.74 \\
\hline Clerical, Administration \& Sales & 26.50 & 21.94 & 28.62 & 26.76 & 29.17 & 24.75 \\
\hline Manual \& Unskilled Working & 33.14 & 21.15 & 29.06 & 22.77 & 38.72 & 40.51 \\
\hline \multicolumn{7}{|l|}{ Class } \\
\hline Working at nonstandard shift (\%) & 34.43 & 22.45 & 28.42 & 33.28 & 42.25 & 39.88 \\
\hline Overwork (\%) & 23.84 & 19.43 & 16.91 & 23.74 & 27.51 & 29.57 \\
\hline Underwork $(\%)$ & 12.83 & 6.72 & 18.85 & 25.70 & 12.53 & 7.08 \\
\hline
\end{tabular}


Table 2. Multivariate Logistic Regressions.

Main Effects of Nonstandard Work, Overworking and Underworking

\begin{tabular}{|c|c|c|c|}
\hline & Nonstandard Work & Overworking & Underworking \\
\hline \multicolumn{4}{|l|}{2005 (ref) } \\
\hline \multirow[t]{2}{*}{2010} & -0.05 & $-0.15^{* * *}$ & $-0.13^{*}$ \\
\hline & $(0.04)$ & $(0.04)$ & $(0.06)$ \\
\hline \multirow[t]{2}{*}{2015} & $0.13^{* * *}$ & -0.06 & 0.05 \\
\hline & $(0.04)$ & $(0.04)$ & $(0.06)$ \\
\hline \multicolumn{4}{|l|}{ Social-Democratic Welfare State (ref) } \\
\hline \multirow{2}{*}{ Corporatist Welfare State } & $0.12^{*}$ & $-0.26^{* * *}$ & $1.39^{* * *}$ \\
\hline & $(0.05)$ & $(0.06)$ & $(0.09)$ \\
\hline \multirow[t]{2}{*}{ Liberal Welfare State } & $0.44^{* * *}$ & $0.17^{*}$ & $1.99^{* * *}$ \\
\hline & $(0.06)$ & $(0.08)$ & $(0.10)$ \\
\hline \multirow[t]{2}{*}{ Southern European Welfare State } & $0.64^{* * *}$ & $0.41^{* * *}$ & $0.91^{* * *}$ \\
\hline & $(0.06)$ & $(0.06)$ & $(0.10)$ \\
\hline \multirow[t]{2}{*}{ Central-Eastern European Welfare State } & $0.65^{* * *}$ & $0.64^{* * *}$ & 0.13 \\
\hline & $(0.05)$ & $(0.06)$ & $(0.10)$ \\
\hline \multirow{2}{*}{ Mothers (ref: fathers) } & $-0.15^{* * *}$ & $-0.91^{* * *}$ & $1.19^{* * *}$ \\
\hline & $(0.04)$ & $(0.04)$ & $(0.07)$ \\
\hline \multicolumn{4}{|l|}{ Tertiary Education (ref) } \\
\hline \multirow{2}{*}{ Primary Education } & $0.54^{* * *}$ & $0.26^{* * *}$ & $-0.31^{* * *}$ \\
\hline & $0.06)$ & $(0.06)$ & $(0.08)$ \\
\hline \multirow[t]{2}{*}{ Secondary Education } & $0.54^{* * *}$ & $0.16^{* * *}$ & $-0.36^{* * *}$ \\
\hline & $(0.04)$ & $(0.05)$ & $(0.07)$ \\
\hline \multicolumn{4}{|l|}{ Managerial \& Professional Occupations (ref) } \\
\hline \multirow{2}{*}{ Clerical, Administration \& Sales } & $0.57^{* * *}$ & -0.04 & $-0.50^{* * *}$ \\
\hline & $(0.04)$ & $(0.05)$ & $(0.06)$ \\
\hline \multirow{2}{*}{ Manual/Non-Manual Working Class } & $0.24^{* * *}$ & -0.05 & $-0.57^{* * *}$ \\
\hline & $(0.05)$ & $(0.05)$ & $(0.07)$ \\
\hline \multicolumn{4}{|l|}{ Top Income Group (Q-4) (ref) } \\
\hline \multirow[t]{2}{*}{ Bottom Income Group (Q-1) } & 0.05 & $-0.88^{* * *}$ & $2.78^{* * *}$ \\
\hline & $(0.05)$ & $(0.06)$ & $(0.10)$ \\
\hline \multirow[t]{2}{*}{ Medium-Low Income Group (Q-2) } & $0.12^{* *}$ & $-0.78^{* * *}$ & $0.93^{* * *}$ \\
\hline & $(0.05)$ & $(0.05)$ & $(0.10)$ \\
\hline \multirow[t]{2}{*}{ Medium-High Income Group (Q-3) } & $0.14^{* *}$ & $-0.65^{* * *}$ & $0.42^{* * *}$ \\
\hline & $(0.04)$ & $(0.05)$ & $(0.10)$ \\
\hline \multirow[t]{2}{*}{ Age } & $-0.01^{* * *}$ & 0.00 & $0.02^{* * *}$ \\
\hline & $(0.00)$ & $(0.00)$ & $(0.00)$ \\
\hline \multirow[t]{2}{*}{ Number of Children } & 0.03 & $0.05^{*}$ & $0.13^{* * *}$ \\
\hline & $(0.02)$ & $(0.02)$ & $(0.03)$ \\
\hline \multirow[t]{2}{*}{ Intercept } & $-1.28^{* * *}$ & 0.14 & $-6.60^{* * *}$ \\
\hline & $(0.13)$ & $(0.14)$ & $(0.24)$ \\
\hline Pseudo $R^{2}$ & 0.05 & 0.08 & 0.26 \\
\hline Observations & 20684 & 20429 & 20429 \\
\hline
\end{tabular}

Note: Numbers represent coefficients with robust standard errors in parentheses. Logistic regression models show the main effects by welfare state, including all independent and control variables of study for our three dependent variables.

${ }^{*} p<.05,{ }^{* *} p<.01,{ }^{* * *} p<.001$ 
Table 3. Multivariate Logistic Regressions. Welfare State Interactions with Year, Gender and Education

\begin{tabular}{|c|c|c|c|c|c|c|c|c|c|}
\hline & \multicolumn{3}{|c|}{ NONSTANDARD WORK } & \multicolumn{3}{|c|}{ OVERWORKING } & \multicolumn{3}{|c|}{ UNDERWORKING } \\
\hline & M-1 & M-2 & M-3 & M-4 & M-5 & M-6 & M-7 & M-8 & M-9 \\
\hline \multicolumn{10}{|l|}{2005 (ref) } \\
\hline \multirow[t]{2}{*}{2010} & -0.13 & -0.05 & -0.05 & 0.22 & $-0.14^{* *}$ & $-0.14^{* *}$ & $-0.45^{*}$ & $-0.14^{*}$ & $-0.13^{*}$ \\
\hline & $(0.11)$ & $(0.04)$ & $(0.04)$ & $(0.11)$ & $(0.04)$ & $(0.04)$ & $(0.19)$ & $(0.06)$ & $(0.06)$ \\
\hline \multirow[t]{2}{*}{2015} & 0.07 & $0.13^{* * *}$ & $0.13^{* * *}$ & $0.24^{*}$ & -0.06 & -0.05 & -0.06 & 0.06 & 0.05 \\
\hline & $(0.10)$ & $(0.04)$ & $(0.04)$ & $(0.11)$ & $(0.04)$ & $(0.04)$ & $(0.18)$ & $(0.06)$ & $(0.06)$ \\
\hline \multicolumn{10}{|l|}{ Social-Democratic Welfare State (SD) (ref) } \\
\hline \multirow[t]{2}{*}{ Corporatist Welfare State (CO) } & 0.06 & $0.24^{* * *}$ & 0.11 & $-0.28^{*}$ & $-0.24^{* * *}$ & -0.15 & $1.41^{* * *}$ & $0.49^{* *}$ & $1.55^{* * *}$ \\
\hline & $(0.10)$ & $(0.07)$ & $(0.08)$ & $(0.11)$ & $(0.07)$ & $(0.08)$ & $(0.15)$ & $(0.18)$ & $(0.13)$ \\
\hline \multirow[t]{2}{*}{ Liberal Welfare State (LI) } & 0.17 & $0.65^{* * *}$ & $0.53^{* * *}$ & $0.36^{* *}$ & $0.37^{* * *}$ & 0.16 & $1.87^{* * *}$ & $0.96^{* * *}$ & $1.95^{* * *}$ \\
\hline & $(0.12)$ & $(0.09)$ & $(0.11)$ & $(0.13)$ & $(0.09)$ & $(0.11)$ & $(0.16)$ & $(0.20)$ & $(0.16)$ \\
\hline \multirow[t]{2}{*}{ Southern European Welfare State (SE) } & $0.56^{* * *}$ & $0.87^{* * * *}$ & $0.48^{* * *}$ & $0.61^{* * *}$ & $0.40^{* * *}$ & 0.09 & $0.50^{* *}$ & $0.65^{* * *}$ & $1.46^{* * *}$ \\
\hline & $(0.09)$ & $(0.08)$ & $(0.10)$ & $(0.10)$ & $(0.08)$ & $(0.10)$ & $(0.17)$ & $(0.19)$ & $(0.16)$ \\
\hline \multirow{2}{*}{$\begin{array}{l}\text { Central-Eastern European Welfare State } \\
\text { (CEE) }\end{array}$} & $0.65^{* * *}$ & $0.69^{* * *}$ & $0.25^{* *}$ & $1.02^{* * *}$ & $0.47^{* * *}$ & 0.12 & -0.03 & $0.47^{* *}$ & $0.94^{* * *}$ \\
\hline & $(0.08)$ & $(0.07)$ & $(0.09)$ & $(0.09)$ & $(0.07)$ & $(0.09)$ & $(0.15)$ & $(0.18)$ & $(0.15)$ \\
\hline Mothers (ref: fathers) & $-0.15^{* * *}$ & 0.08 & $-0.14^{* * *}$ & $-0.91^{* * *}$ & $-1.02^{* * *}$ & $-0.91^{* * *}$ & $1.19^{* * *}$ & $0.65^{* * *}$ & $1.19^{* * *}$ \\
\hline & $(0.04)$ & $(0.09)$ & $(0.04)$ & $(0.04)$ & $(0.10)$ & $(0.04)$ & $(0.07)$ & $(0.17)$ & $(0.07)$ \\
\hline Tertiary Education (ref) & & & & & & & & & \\
\hline Primary Education & $0.55^{* * *}$ & $0.54^{* * *}$ & $0.36^{*}$ & $0.26^{* * *}$ & $0.25^{* * *}$ & 0.17 & $-0.33^{* * *}$ & $-0.31^{* * *}$ & 0.18 \\
\hline & $(0.06)$ & $(0.06)$ & $(0.17)$ & $(0.06)$ & $(0.06)$ & $(0.19)$ & $(0.08)$ & $(0.08)$ & $(0.29)$ \\
\hline Secondary Education & $0.55^{* * *}$ & $0.55^{* * *}$ & $0.33^{* * *}$ & $0.16^{* * *}$ & $0.16^{* * *}$ & -0.19 & $-0.37^{* * * *}$ & $-0.35^{* * *}$ & 0.13 \\
\hline & $(0.04)$ & $(0.04)$ & $(0.09)$ & $(0.05)$ & $(0.05)$ & $(0.10)$ & $(0.07)$ & $(0.07)$ & $(0.16)$ \\
\hline CO $x$ year $=2010$ & 0.16 & & & -0.08 & & & 0.11 & & \\
\hline & $(0.13)$ & & & $(0.15)$ & & & $(0.21)$ & & \\
\hline $\mathrm{CO} \times$ year $=2015$ & 0.00 & & & 0.02 & & & -0.03 & & \\
\hline & $(0.13)$ & & & $(0.15)$ & & & $(0.20)$ & & \\
\hline LI $x$ year $=2010$ & $0.36^{*}$ & & & $-0.49^{*}$ & & & $0.71^{* *}$ & & \\
\hline & $(0.18)$ & & & $(0.19)$ & & & $(0.24)$ & & \\
\hline LI $x$ year $=2015$ & $0.42^{*}$ & & & -0.16 & & & -0.24 & & \\
\hline & $(0.17)$ & & & $(0.18)$ & & & $(0.23)$ & & \\
\hline SE $x$ year $=2010$ & 0.02 & & & -0.29 & & & 0.49 & & \\
\hline & $(0.14)$ & & & $(0.15)$ & & & $(0.25)$ & & \\
\hline SE $\times$ year $=2015$ & 0.19 & & & $-0.31^{*}$ & & & $0.64^{* *}$ & & \\
\hline & $(0.13)$ & & & $(0.14)$ & & & $(0.23)$ & & \\
\hline CEE $x$ year $=2010$ & 0.03 & & & $-0.62^{* * *}$ & & & $0.47^{*}$ & & \\
\hline & $(0.12)$ & & & $(0.13)$ & & & $(0.23)$ & & \\
\hline CEE $x$ year $=2015$ & -0.03 & & & $-0.59^{* * *}$ & & & 0.07 & & \\
\hline & $(0.12)$ & & & $(0.13)$ & & & $(0.22)$ & & \\
\hline $\mathrm{CO} \times$ Mothers & & $-0.26^{*}$ & & & -0.07 & & & $1.14^{* * *}$ & \\
\hline & & $(0.11)$ & & & $(0.13)$ & & & $(0.20)$ & \\
\hline LI x Mothers & & $-0.46^{* *}$ & & & $-0.83^{* * *}$ & & & $1.40^{* * *}$ & \\
\hline & & $(0.14)$ & & & $(0.19)$ & & & $(0.23)$ & \\
\hline SE x Mothers & & $-0.50^{* * *}$ & & & 0.04 & & & 0.31 & \\
\hline & & $(0.11)$ & & & $(0.13)$ & & & $(0.21)$ & \\
\hline CEE $x$ Mothers & & -0.11 & & & $0.41^{* * * *}$ & & & $-0.46^{*}$ & \\
\hline & & $(0.10)$ & & & $(0.12)$ & & & $(0.21)$ & \\
\hline $\mathrm{CO}$ x Primary Education & & & -0.04 & & & $-0.42^{*}$ & & & -0.36 \\
\hline & & & $(0.19)$ & & & $(0.21)$ & & & $(0.31)$ \\
\hline $\mathrm{CO}$ x Secondary Education & & & 0.08 & & & -0.03 & & & -0.33 \\
\hline & & & $(0.11)$ & & & $(0.13)$ & & & $(0.18)$ \\
\hline LI x Primary Education & & & -0.13 & & & -0.17 & & & -0.19 \\
\hline & & & $(0.22)$ & & & $(0.24)$ & & & $(0.33)$ \\
\hline LI x Secondary Education & & & -0.16 & & & 0.16 & & & 0.11 \\
\hline & & & $(0.15)$ & & & $(0.17)$ & & & $(0.22)$ \\
\hline SE $x$ Primary Education & & & 0.28 & & & $0.46^{*}$ & & & $-1.01^{* *}$ \\
\hline & & & $(0.19)$ & & & $(0.21)$ & & & $(0.33)$ \\
\hline SE x Secondary Education & & & 0.24 & & & $0.48^{* * *}$ & & & $-0.80^{* * *}$ \\
\hline & & & $(0.13)$ & & & $(0.14)$ & & & $(0.21)$ \\
\hline CEE $x$ Primary Education & & & $0.55^{* *}$ & & & $0.47^{*}$ & & & $-0.92^{* *}$ \\
\hline & & & $(0.19)$ & & & $(0.21)$ & & & $(0.33)$ \\
\hline CEE x Secondary Education & & & $0.56^{* * *}$ & & & $0.87^{* * *}$ & & & $-1.38^{* * *}$ \\
\hline & & & $(0.11)$ & & & $(0.12)$ & & & $(0.20)$ \\
\hline Intercept & $-1.25^{* * *}$ & $-1.53^{* * *}$ & $-1.16^{* * *}$ & -0.08 & $-0.74^{* * *}$ & $0.31^{*}$ & $-6.49^{* * *}$ & $-4.96^{* * *}$ & $-6.92^{* * *}$ \\
\hline & $(0.14)$ & $(0.12)$ & $(0.13)$ & $(0.16)$ & $(0.13)$ & $(0.15)$ & $(0.26)$ & $(0.24)$ & $(0.26)$ \\
\hline Pseudo $R^{2}$ & 0.048 & 0.05 & 0.05 & 0.085 & 0.09 & 0.09 & 0.268 & 0.28 & 0.27 \\
\hline Observations & & 20684 & & & 20429 & & & 20429 & \\
\hline
\end{tabular}

Note: Numbers represent coefficients with robust standard errors in parentheses. Analyses present the interaction effects between welfare state and (i) year, (ii) gender and (iii) education for out three dependent variables: nonstandard work schedule, overworking and underworking. All models control for occupational class, income, age and number of children at home. ${ }^{*} p<.05,{ }^{* *} p<.01,{ }^{* * *} p<.001$ 


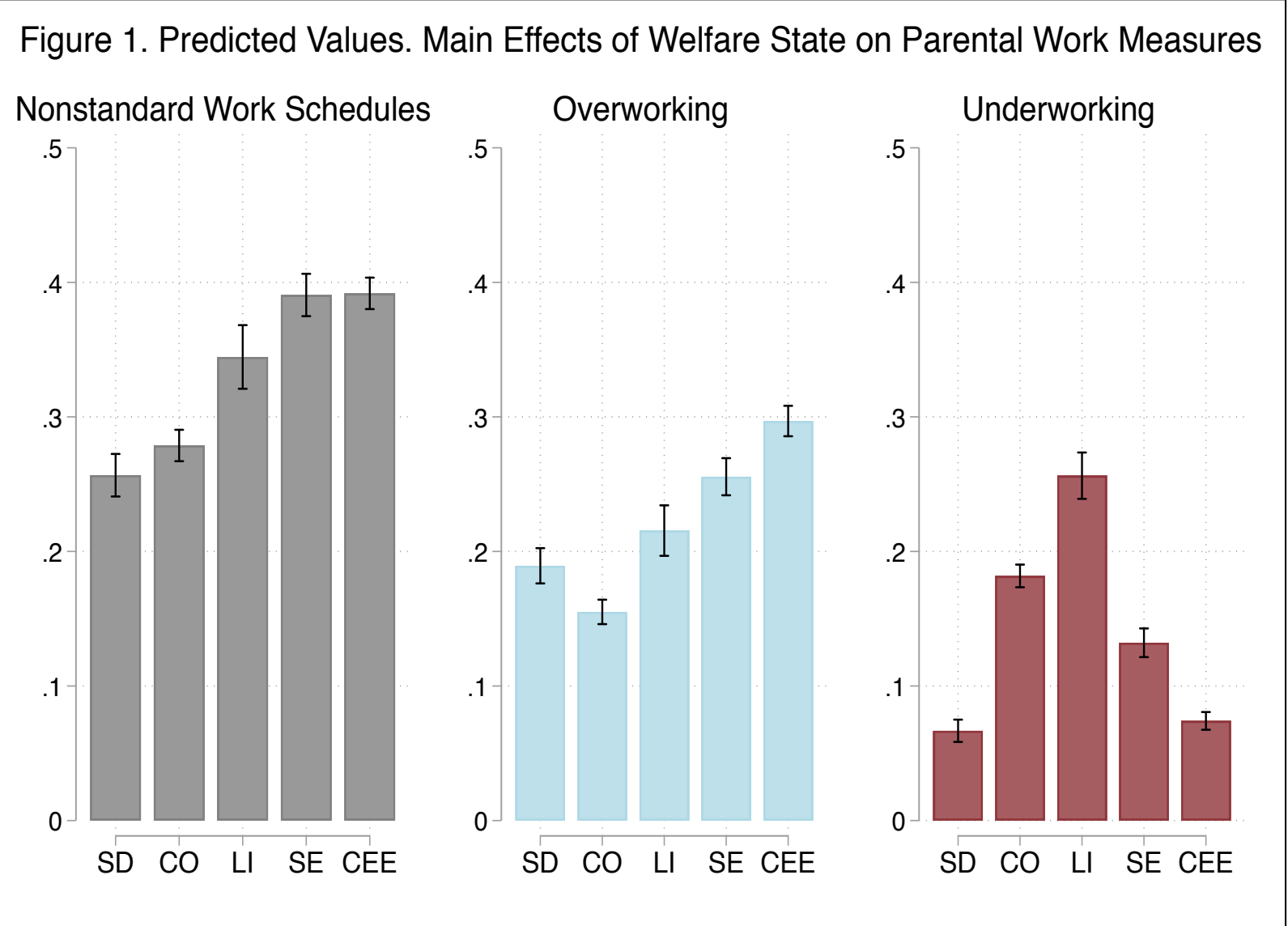

Note: Predicted values based on the multivariate logistic regressions presented in Table 2; SD $=$ Scandinavian Social-Democratic; $\mathrm{CO}=$ Corporatist; LI = Liberal; $\mathrm{SE}=$ Southern European; CEE = Central-Eastern European. Confidence Intervals at the $95 \%$ are included in brackets. 
Figure 2. Predicted Values. Nonstandard Work Schedules, Overworking and Underworking

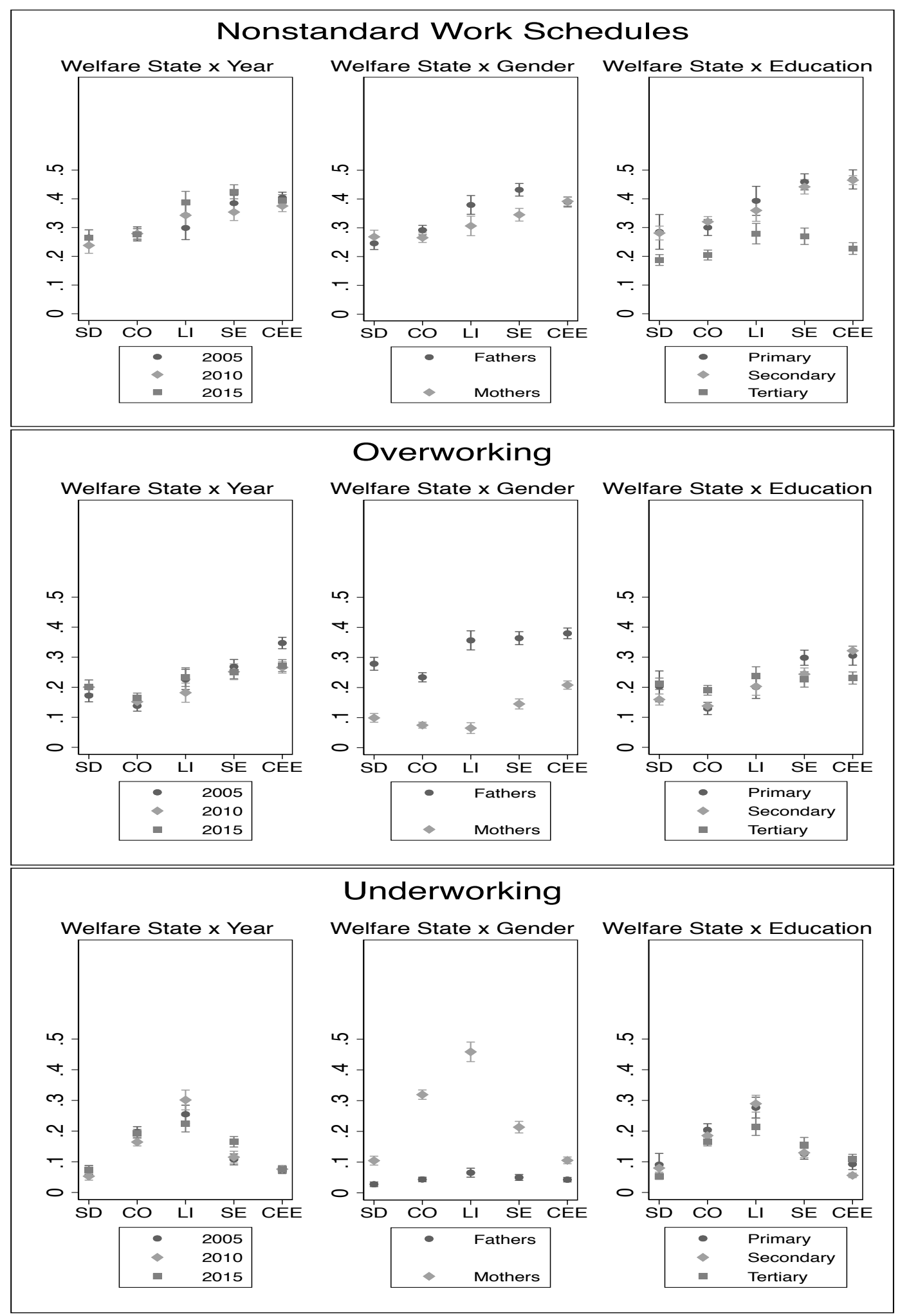

Note: Results of Logistic Regressions with interaction effects presented in Table 3, full models, with C.I. at $95 \%$ in brackets (SD $=$ SocialDemocratic; $\mathrm{CO}=$ Corporatist; $\mathrm{LI}=$ Liberal; $\mathrm{SE}=$ Southern European; $\mathrm{CEE}=$ East-Central European). 
Figure A1. Distribution of Nonstandard Work Schedules, Overworking, and Underworking by Welfare State Regime, Gender and Year (2005-2015)
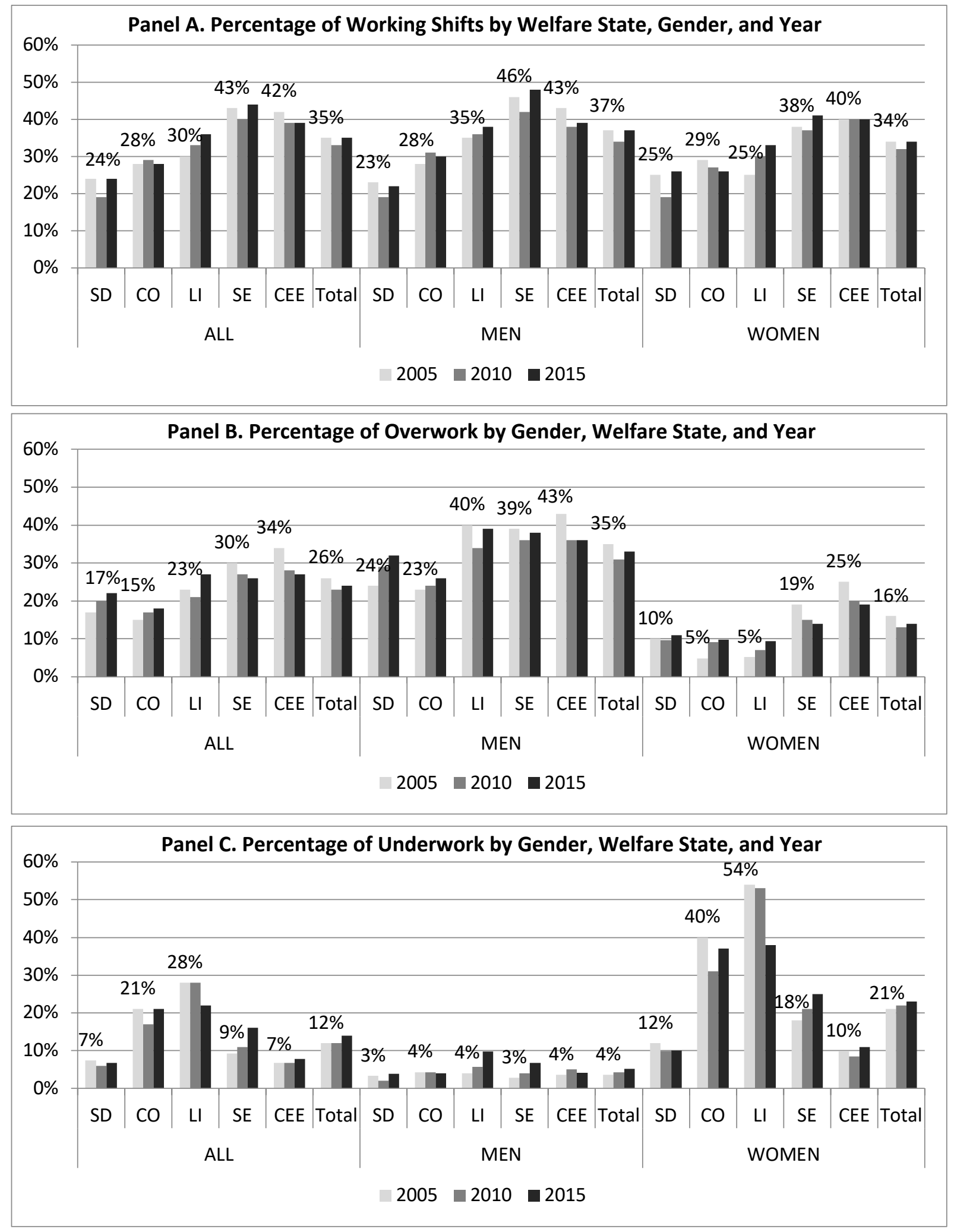
Figure A2. Predicted Values of Parental Work in 29 Countries
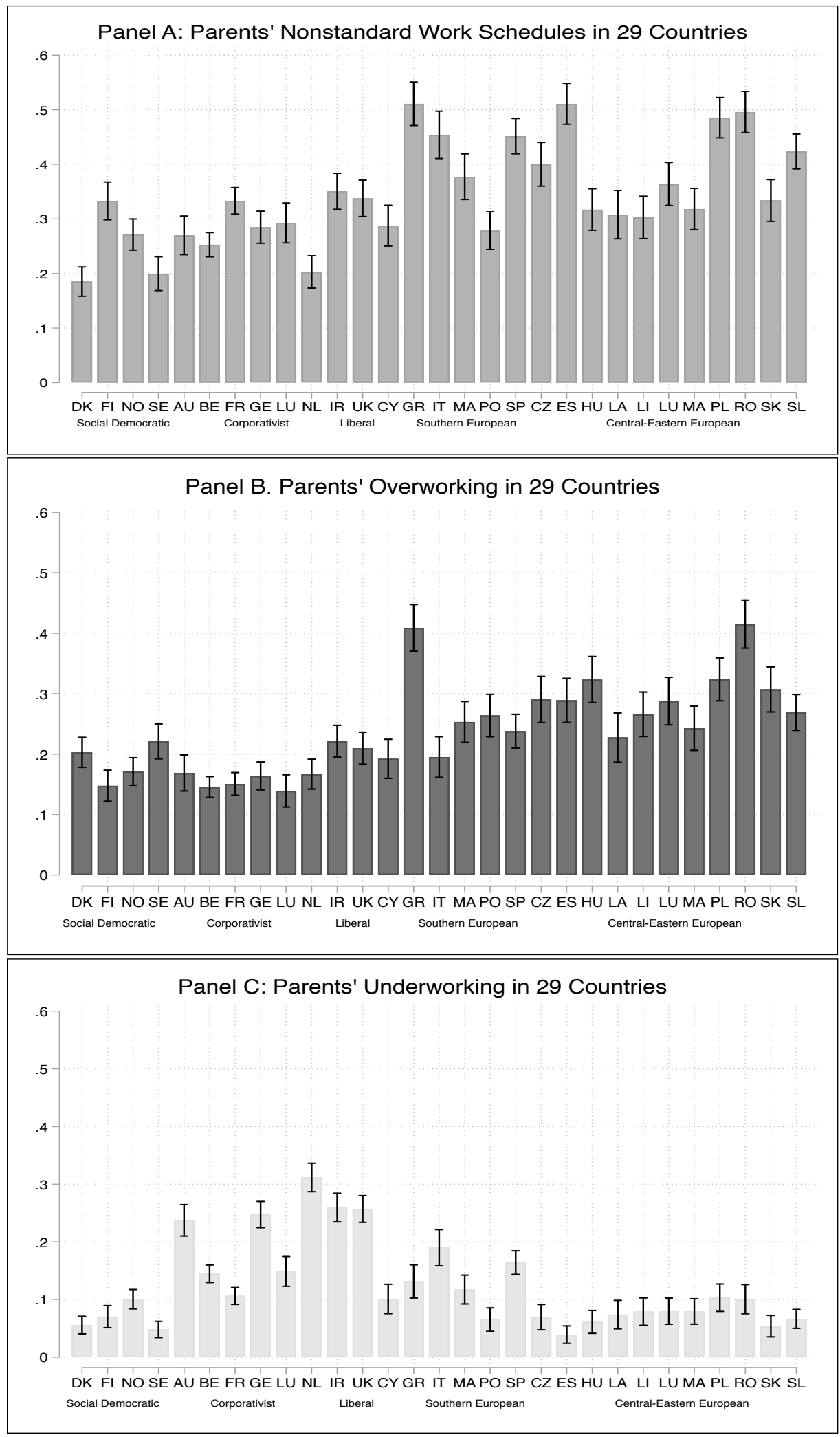

Note: Predicted values based on country dummy marginal effects. Models are conducted for three separate multivariate logistic regressions, including all control variables of the study in each empirical model. CI at $95 \%$ are included in brackets 